\title{
Isolation of Staphylococcus aureus from ear swab in Iraqi children as a causative agent of Otitis externa
}

\author{
Eman A. Al-Hasnawi* BSc, MSc
}

Abstract:

Fac Med Baghdad 2017; Vol.59, No.3 Received: April 2017 Accepted: Aug. 2017
Background: Staphylococcus aureus is a Gram-positive, spherical, grape like clusters arrangment bacterium, non-spore forming. Is a genus that causes many hard diseases such as food poisoning, gastroenteritis with severe symptoms. S. aureus is commonly found in the wide environment (soil, air and water) and is importantly found in the nose and skin in the humans. And can causes ear infection by entering the ear. The diagnosis of Otitis externa is usually made clinically and bacterial tests.

Objective: To detection and isolation of the bacteria Staphylococcus aureus from pus specimens of ear swab, among Iraqi children with Otitis externa.

Patients and methods: Eighty ear swab specimens from suspected cases of Otitis externa among children, inoculated to brain heart broth, then to non-selective media (blood agar) and when growth appeared, cultured on selective media (Mannitol salt agar) plates in the laboratory. The plates were incubated at $37^{\circ} \mathrm{C}$ aerobically for 24 hours, identified the isolate by Gram stain, catalase and coagulase of human plasma.

Results: In this study, from 80 samples (43) males; (37) female, with (31) cases had medical history controlled by 20 healthy individuals: the bacterial growth and identification on blood agar resulted in presence of nonspecific bacteria in (65) samples, were (36) males and (29) females, while specific bacteria Staphylococcus aureus on selected media (Manitol salt agar), catalase positive and Co-agulase positive, were in (28) samples of (16) males and (12) females most of them in age (1-3) years, were (11) samples, in males more than females.

Conclusion: The isolation of Staphylococcus aureus was the most important diagnosis of predominant causative agents of Otitis externa among Iraqi children and showed such an exhibition about the epidemic type of bacteria in our region.

Keywords: Staphylococcus aureus, Otitis externa , ear swab, Iraqi children

\section{Introduction:}

Ear infection is a predominant problem for both children and adults, it can be caused by viruses and fungi but the most causes of ear infection (otitis externa) is bacterial [1]. S. aureus is a Gram-positive, spherical bacterium, non-spore forming, arranged in grape like clusters [2]. The Staphylococcus genus is include about 32 species that can produces enterotoxin (SE) that responsible for most of severe staphylococcal food poisoning [3]. S. aureus that nasal carriage often lead to infection. The bacterium inhabitant of humans and some of animal species colonizes the skin and the host mucosa. Although multiple sites of body can be colonized in many parts of human beings, the anterior nares of the nose are from the main body sites [3]. Staphylococcus aureus is an important part of the system in humans normal flora, other mammals and even in birds [4]. In humans, the region in the anterior nares are act the main inhabitant sites of $\mathrm{S}$. aureus colonization, include the throat, skin, vagina and perineum [5]. Based on longwise studies with repeated samples many of

\footnotetext{
*Dept. of Pathological analysis, Institute of Medical technology /Al-Mansour Middle Technical University ealhasnawi@gmail.com
}

population has S. aureus nasal carriage patterns: The persistent carriers, about $20 \%$ of the individuals (range from at $12-32 \%$ are carriers) [6]. Otitis externa is the usual inflammation occurs in the mucous membrane in human, especially in children, that belonging to the middle ear, the inflammation is often associated with a discharge from the ear canal through a penetration of the tympanic membrane, and otitis media occurs [7]. It causes many signs such as ear pain, pulling or tugging at the ear, Fever, sleeping less, deafness and discharging fluids from the ear [8]. Acute otitis externa is the most predominant identified infectious disease of childhood period [9]. Recent researches explained that the number of cases has highly increased among children and this may be predicated in part to the increase at the past of two decades in the number of children that had and attending daily care [10]. The major causes of ear infection are bacteria such as Pseudomonas aeruginosa, with many strains, Staphylococcus aureus and with Co-agulase Negative Staphylococci, Proteus species, Klebsiella pneumonia and Escherichia coli [11]. The diagnosis of Otitis externa is usually made clinically [12]. in uncertain cases, the cultures of Nasopharyngeal samples "have only a $47 \%$ positive predictive value in determining 
the etiologic agent when compared with middle ear aspiration" [13]. Labyrinthitis: Often causes dizziness and imbalance by inflammation of the inner ear [14]. Mastoiditis: an infection of the skull and variant degrees of infection of the brain membranes with spinal cord (meningitis). Scarring occurs and thicknesses in the eardrum Facial paralysis and gradually hearing loss [15]. Staphylococcus aureus bacteria was the dominant cause of Acute suppurative otitis externa in children with the percentage of $49.23 \%$ among other causative bacteria in ALDiwaniya City, in Iraq, in 2007 [16].

\section{Methods:}

Sampling: Eighty $(n=80)$ ear swab specimens all were collected clinically from suspected cases of ear infection (otitis externa) among children and inoculated to brain heart broth, they were aged about (1-12 years) arrived the unit of ENT in Central teaching hospital of children with (20) samples of ear swabs from healthy children as control, in Baghdad during period of the study from August 2016- January 2017. Bacteriology method: Each ear swab sample was inoculated to non-selective media blood agar and when growth appeared, cultured on selective media, into Mannitol salt agar plates in the laboratory. The plates were incubated at $37^{\circ} \mathrm{C}$ aerobically for 24 hours. Confirmed diagnosis of growth present on agar by using the catalase enzyme test and Co-agulase enzyme test, then the growth that had positive results of both tests were also identified by slide smear, using gram stain and tested microscopically for appearance of bacteria as clustered, cocci with purple color for determination and detection of Staphylococcus aureus [17].

\section{Results:}

Study group with Age, Gender and Medical history: The study had from 80 samples (43) males; (37) female, with (31) cases had medical history controlled by 20 healthy individuals. The most cases of otitis media were in the age group (1-3) acted 25(31\%) and the high number contributed with male gender (14) patients.

Table (1): Show Otitis Externa patients' age, gender, medical history \& control

\begin{tabular}{|c|c|c|c|c|c|c|c|}
\hline \multirow[t]{2}{*}{$\begin{array}{l}\text { Age } \\
\text { groups }\end{array}$} & \multicolumn{2}{|c|}{$\mathrm{N}=80$} & \multicolumn{2}{|c|}{ Gender } & \multirow[t]{2}{*}{$\begin{array}{l}\text { Medical } \\
\text { history of } \\
\text { infection }\end{array}$} & \multicolumn{2}{|c|}{$\begin{array}{l}\text { Healthy } \\
\text { control } \\
\mathrm{N}=20\end{array}$} \\
\hline & $\mathrm{n}$ & $\%$ & $\mathrm{M}$ & $\mathrm{F}$ & & $\mathrm{n}$ & $\%$ \\
\hline $\begin{array}{l}(1-3) \\
\text { years }\end{array}$ & 25 & 31 & 14 & 11 & (1-3) years & 25 & 31 \\
\hline $\begin{array}{l}(4-6) \\
\text { years }\end{array}$ & 21 & 26 & 12 & 9 & (4-6) years & 21 & 26 \\
\hline $\begin{array}{l}(5-9) \\
\text { years }\end{array}$ & 18 & 23 & 8 & 10 & (5-9) years & 18 & 23 \\
\hline $\begin{array}{c}(10-12) \\
\text { years }\end{array}$ & 16 & 20 & 9 & 7 & $\begin{array}{c}(10-12) \\
\text { years }\end{array}$ & 16 & 20 \\
\hline Toal & 80 & 100 & 43 & 37 & Toal & 80 & 100 \\
\hline
\end{tabular}

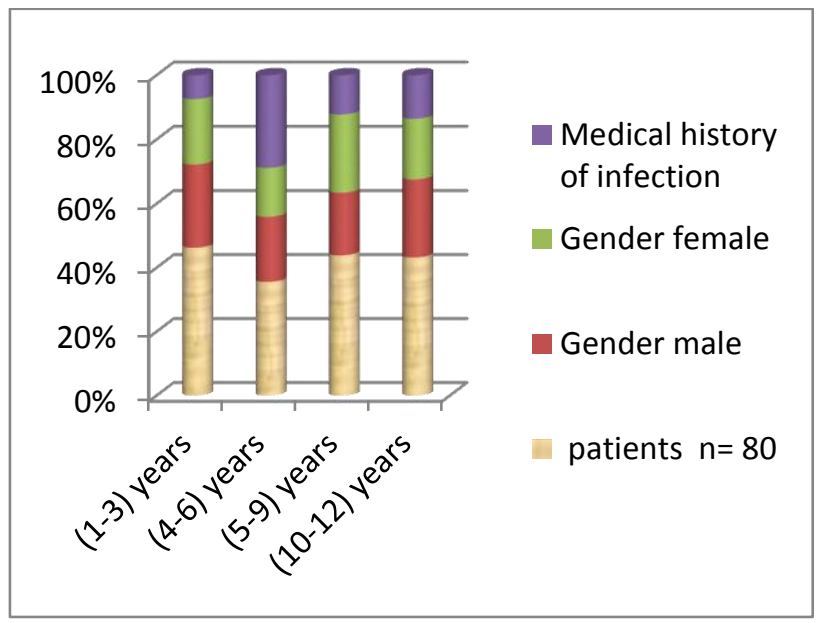

Figure (1): Otitis Externa study group by age, gender and medical history

Culture on Blood Agar:The growth culture characters with presence of nonspecific bacteria (mixture of many bacteria) included Staphylococcus aureus. The bacterial growth and identification on blood agar resulted in presence of a high number of nonspecific bacteria in (65) samples, were (36) males and (29) females.

Table (2): Results of Nonspecific Bacteria on Blood Agar with Age \& Gender

\begin{tabular}{|c|c|c|c|c|c|c|c|}
\hline \multirow[t]{2}{*}{ Age groups } & \multicolumn{2}{|c|}{$N=65$} & \multicolumn{2}{|c|}{ Gender } & \multirow{2}{*}{$\begin{array}{l}\text { Medical } \\
\text { history of } \\
\text { infection }\end{array}$} & \multicolumn{2}{|c|}{$\begin{array}{l}\text { Healthy } \\
\text { control }\end{array}$} \\
\hline & $\mathrm{n}$ & $\%$ & M & $\mathrm{F}$ & & $\mathrm{n}$ & $\%$ \\
\hline$(1-3)$ years & 23 & 35 & 11 & 9 & 4 & 4 & 45 \\
\hline (4-6) years & 14 & 22 & 10 & 7 & 17 & 3 & 33 \\
\hline$(5-9)$ years & 17 & 26 & 7 & 7 & 5 & 1 & 11 \\
\hline $\begin{array}{l}(10-12) \\
\text { years }\end{array}$ & 11 & 17 & 8 & 6 & 5 & 1 & 11 \\
\hline Toal & 65 & 100 & 36 & 29 & 31 & 9 & 100 \\
\hline
\end{tabular}

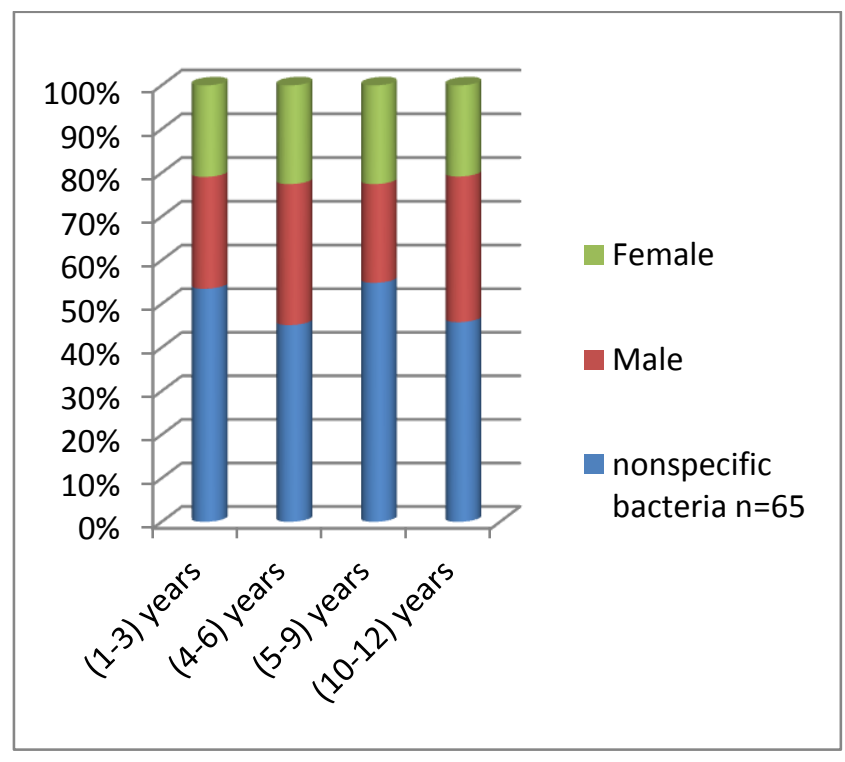

Figure (2): Results of Nonspecific Bacteria on Blood Agar with Age and Gender 
Specific Bacteria Staphylococcus aureus: The specific bacteria Staphylococcus aureus on selected media (Manitol salt agar) catalase positive and Co-agulase positive, were detected in (28) samples of (16) males and (12) females most of them in age (1-3) years, were (11) samples, in males more than females.

Table (3): Staphylococcus aureus positive results with age and gender

\begin{tabular}{|c|c|c|c|c|c|c|c|}
\hline \multirow[t]{2}{*}{$\begin{array}{l}\text { Age } \\
\text { groups }\end{array}$} & \multicolumn{2}{|c|}{$\mathrm{N}=28$} & \multicolumn{2}{|c|}{ Gender } & \multirow{2}{*}{$\begin{array}{l}\text { Medical } \\
\text { history of } \\
\text { infection }\end{array}$} & \multicolumn{2}{|c|}{$\begin{array}{l}\text { Healthy } \\
\text { control }\end{array}$} \\
\hline & $\mathrm{n}$ & $\%$ & M & $\mathrm{F}$ & & $\mathrm{n}$ & $\%$ \\
\hline$(1-3)$ & 11 & 39 & 7 & 4 & 4 & 1 & 50 \\
\hline \multicolumn{8}{|l|}{ years } \\
\hline$(4-6)$ & 6 & 21 & 3 & 3 & 17 & 0 & 0 \\
\hline years & & & & & & & \\
\hline$(5-9)$ & 8 & 29 & 5 & 3 & 5 & 0 & 0 \\
\hline years & & & & & & & \\
\hline $\begin{array}{l}(10-12) \\
\text { years }\end{array}$ & 3 & 11 & 1 & 2 & 5 & 1 & 50 \\
\hline Toal & 28 & 100 & 16 & 12 & 31 & 2 & 100 \\
\hline
\end{tabular}

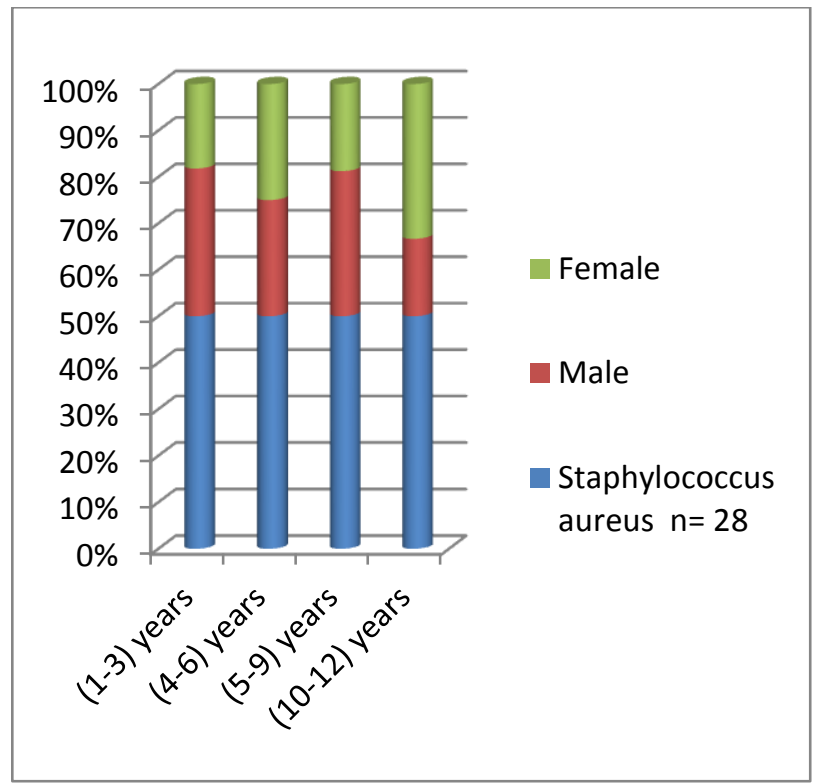

Figure (3): Staphylococcus aureus positive results with age and gender

\section{Discussion:}

In this study, from 80 samples (43) males; (37) female, with (31) cases had medical history controlled by 20 healthy individuals. The most cases of otitis externa were in the age group (1-3) acted $25(31 \%)$ and the high number contributed with male gender (14), and this agree with [13,18]: "male gender, and passive exposure to smoking have been associated with an increased likelihood of recurrence".

The growth culture on none specific media, blood agar (table 2) characters with presence of nonspecific bacteria (mixture of many bacteria) included Staphylococcus aureus. The bacterial growth and identification on blood agar resulted in presence of a high number of nonspecific bacteria in (65) samples, were (36) males and (29) females. This result because of multifactorial and multi-bacterial causes of ear infection and this agree with [7]: "The major causes of ear infection (otitis externa) are bacteria such as Pseudomonas aeruginosa, Staphylococcus aureus, Coagulase Negative Staphylococci, Proteus species, Klebsiella pneumonia and Escherichia coli".

From a total of 80 samples were included in the study, $28(35 \%)$ showed positive bacterial growth of Staphylococcus aureus, (37) samples were another growth and (15) samples had no any bacterial growth. And this agreed with "Staphylococcus aureus are the most common aerobic microbial isolates in patients with Otitis externa, followed by Proteus vulgaris and Klebsiella pneumonia" $[11,12]$. The most of positive cases were in male at age (1-3) years, especially in those with of medical history of infection and this might be because of uncompleted immune system in children at this younger age, and this agree with [14]: "Children are much more susceptible to otitis externa since the Eustachian tube is short and at more of a horizontal angle than in the adult ear".

The specific bacteria Staphylococcus aureus on selected media (Manitol salt agar) as showed in (table 3) with backed diagnosis by catalase positive and Coagulase positive, were detected in (28) samples of (16) males and (12) females most of them in age (1-3) years, were (11) samples, in males more than females. Isolates were by morphological test of colonies, characteristics microscopically as that were searched of Gram-positive cocci, catalase positive and coagulase positive of human plasma, if all these tests are positive, the bacteria will considered as Staphylococcus aureus in this study. And this agreed with "The diagnosis is primarily clinical and often joined by microbiological confirmation tests and the Otoscopic examination is very important method for primarily diagnosis of ear infection (otitis externa)" [8]. "The growth and survival of S. aureus is dependent on a number of environmental factors such as temperature, water activity (aw), and $\mathrm{pH}$, the presence of oxygen and composition of the food. These physical growth parameters vary for different $\mathrm{S}$. aureus strains" [9]. This high number of S. aureus in ear swabs of the children with otitis externa because of presence of $\mathrm{S}$. aureus as normal flora in nasal site that consider as an natural inhabit of organism in many individuals. And this agreed with "Most studies that carried out on S. aureus as nasal carriage have used a cross-sectional study type with a several nasal swabs culture to classify an individual as a carrier or not" [19]. So the suggestion was to produce Staphylococcus aureus vaccine to prevent the nasal site to be a source to causes of infection with otitis externa or other infections [20, 21]. 

agent of Otitis externa

\section{Conclusions:}

The redness and inflammation of Tympanic membrane in Otitis externa, make it hard and unclear to diagnose them by otoscopy. Therefore, the most important diagnosis was by microbiological laboratory tests. and the isolation of Staphylococcus aureus was the most important diagnosis to be a significant bacteria among predominant causative agents of otitis externa occurred among Iraqi children and offered such an exhibition of information about the demography and epidemic type of predominant bacteria present in this region.

\section{References:}

1. Muluye D., Wondimeneh Y., Ferede G., Moges F. and Nega T. Bacterial isolates and drug susceptibility patterns of ear discharge from patients with ear infection at Gondar University Hospital, Northwest Ethiopia. (2013).BioMed central. 13.p.10.

2. Montville TJ, Matthews KR, Food microbiology: An introduction. 2nd ed, (2008) ASM Press, Washington D.C. (IVSL)

3. Fluit AC: Livestock-associated Staphylococcus aureus. Clin Microbiol Infect 2012, 18(8):735- 744.

4. Wertheim HF, Verveer J, Boelens HA, van Belkum A, Verbrugh HA, Vos MC: Effect of mupirocin treatment on nasal, pharyngeal, and perineal carriage of Staphylococcus aureus in healthy adults. Antimicrob Agents Chemother 2005, 49(4):1465-1467. 5. van Hal SJ, Jensen SO, Vaska VL, Espedido BA, Paterson DL, Gosbell IB: Predictors of mortality in Staphylococcus aureus Bacteremia. Clin Microbiol Rev 2012, 25(2):362-386.

6. 19.Ilechukwu C. G., Ubesie C.A., Ojinnaka N.C., Emechebe O.G. and Iloh K.K. Otitis externa in Children. Open Journal of Pediatrics. (2014). 4.p.4753.

7. Combs JT. The diagnosis of otitis externa: new techniques. Pediatr Infect Dis 1 1994; 13:1039-46.

8. Satish S.H., Viswanatha B. and Manjuladevi M. A Clinical Study of Otomycosis. IOSR Journal of Dental and Medical Science. (2013). 5 (2).p.57-58.

9. Stewart CM (2003) Staphylococcus aureus and staphylococcal enterotoxins. Ch 12 In: Hocking AD (ed) Foodborne microorganisms of public health significance. 6th ed, Australian Institute of Food Science and Technology (NSW Branch), Sydney, $p$. 359-380.

10. American Academy of Pediatrics Division of Publications PO Box 747 Elk Grove Village, IL 60009-0747. 1996. Web site - http://www.aap.org.

11.Sattar, A., Alamgir, A., Hussain, Z., Sarfraz, S., Nasir, J. \& Badar-e-Alam Bacterial spectrum and their sensitivity pattern in patients of chronic suppurative otitis media. J Coll Physicians Surg Pak. (2012). 22, 128-129.

12. Aduda, D. S., Macharia, I. M., Mugwe, P., Oburra, H., Farragher, B., Brabin, B. \& Mackenzie, Bacteriology of chronic suppurative otitis media (CSOM) in children in Garissa district, Kenya: a point prevalence study. Int J Pediatr Otorhinolaryngol I. (2013). 77, 1107-1111. (IVSL)

13. Damoiseaux RA, Rovers MM, Van Balen FA, Hoes AW, de Melker RA. Long-term prognosis of acute otitis media in infancy: determinants of recurrent acute otitis media and persistent middle ear effusion. Fam Pract. 2006;23(1):40-45.

14. Little P, Gould C, Moore M, Warner G, Dunleavey $J$, Williamson I. Predictors of poor outcome and benefits from antibiotics in children with acute otitis media: pragmatic randomised trial. BMJ. $2002 \mathrm{Jul}$ 6;325(7354):22. (IVSL)

15. Malachowa, N.; Kobayashi, S.D.; Braughton, K.R.; Whitney, A.R.; Parnell, M.J.; Gardner, D.J.; Deleo, F.R. Staphylococcus aureus leukotoxin gh promotes inflammation. J. Infect. Dis. 2012, 206, 1185-1193.

16. Enas Mohamad $M$ and Ebtesam Thamer J. Iraqi Journal of Science

ISSN: 00672904 Year: 2010 Volume: 51 Issue: 3Pages: 351-359 Publisher: Baghdad University.

17. Misstear, K.; McNeela, E.A.; Murphy, A.G.; Geoghegan, J.A.; O'Keeffe, K.M.; Fox, J.; Chan, K.; Heuking, S.; Collin, N.; Foster, T.J.; et al. Targeted nasal vaccination provides antibody-independent protection against Staphylococcus aureus. J. Infect. Dis. 2014, 209, 1479-1484.

18. Wiese, L.; Mejer, N.; Schonheyder, H.C.; Westh, H.; Jensen, A.G.; Larsen, A.R.; Skov, R.; Benfield, T. A nationwide study of comorbidity and risk of reinfection after Staphylococcus aureus bacteraemia. 2013, 67, 199-205.

19. David, M.Z.; Daum, R.S. Community-associated methicillin-resistant Staphylococcus aureus: Epidemiology and clinical consequences of an emerging epidemic. Clin. Microbiol. Rev. 2010, 23, 616-687.

20. Fowler, V.G., Jr.; Proctor, R.A. Where does a Staphylococcus aureus vaccine stand? Clin. Microbiol. Infect. 2014, 20 (Suppl. 5), 66-75.

21.Daum, R.S.; Spellberg, B. Progress toward a Staphylococcus aureus vaccine. Clin. Infect. Dis. 2012, 54, 560-567. 